\title{
Studi Penyerapan Energi Beban Kejut Laminasi Komposit Epoxy-Karet
}

\author{
A. Kurniawan, K. A. Widi, M. A. Uhib, P. S. Saskara, M. A. Dwipayana, G. N. R. Wijaya, A. Rizaldi, P. W. S. P. \\ Arisudana ${ }^{1}$ \\ ${ }^{1}$ Teknik Mesin Institut Teknologi Nasional Malang \\ Email: arif.kurniawan@lecturer.itn.ac.id
}

\begin{abstract}
Penelitian ini untuk memenuhi kebutuhan panel rompi anti peluru. Dengan menggunakan material komposit di maksudkan untuk mengurangi kelemahan penggunaan logam sebagai panel rompi anti peluru adalah sifatnya yang dapat mengabsorbsi air dan juga berat sehingga dapat menurunkan sifat mekaniknya. Untuk itu dilakukan penelitian ini menggunaan material komposit yang terdiri dari serat karbon kevlar,serat rami, dan serat agave, sebagai penguat material komposit anti peluru dipilih mengingat karakteristik fisikal yang sangat baik. Sifatnya yang kuat, ringan, tahan terhadap panas sampai dengan suhu 400_C, stabil secara kimia dan fleksibel sangat mendukung untuk penggunaannya sebagai bahan dasar penyusun komposit material anti peluru. Matriks penyusun komposit adalah resin dengan jenis resin epoxy dan di padukan dengan karet dengan variasi campuran 30\%,40\% dan 50\% karet sebagai matriks nya dan serat karbon kevlar,serat rami ,serat agave sebagai penguat. Metode pembuatan dilakukan dengan teknik penaburan serat karbon yang kemudian dilaminasi secara kontinyu dengan sistem resin atau di sebut juga metode hand lay up. Hasil uji laboratorium yaitu uji tembak langsung yang akan di adakan di Pusdik Arhanud, sehingga dapat mengetahui seberapa kuat komposit ini terhadap peluru. Karena keterbatasan peluru saat pengujian tembak di Pusdik Arhanud, kami melakukan uji impact untuk menentukan campuran mana yang paling kuat untuk di uji tembak. Hasil dari uji impact menunjukan variasi campuran karet dengan 30\% karet yang memiliki kekuatan tertinggi dan spesimen kering dengan cepat dan tepat. Dengan Teknik hand lay up kami membuat rompi anti peluru dengan variasi campuran karet $30 \%$.
\end{abstract}

Keywords Matrik epoxy, silicon rubber, komposit tahan peluru, stuktur makro.

Paper type Research paper

\section{PENDAHULUAN}

Pada suatu negara pasti memiliki kekuatan militer untuk melindungi negara masing-masing, termasuk di Indonesia [4]. Di dalam dunia militer pada angkatan bersenjata kelengkapan pertahanan dan perlindungan diri merupakan suatu hal yang sangat penting, salah satunya adalah panel rompi anti peluru. panel rompi anti peluru berfungsi untuk menahan penetrasi dan dapat mereduksi energi impact yang ditimbulkan oleh peluru. Saat terjadi tumbukan antara permukaan rompi energi kinetik peluru diserap dan didistribusikan pada luasan permukaan keras pada rompi dan energi yang tersisa akan mengenai ke bagian dada dan perut militer tersebut [1].

Dalam penelitian ini bahan utama yang digunakan adalah epoxy sebagai bahan pengikat (matrik) yang dikombinasikan dengan karet, dengan variasi campuran karet sebesar 30\% karet, 40\% karet dan 50\% karet bertujuan untuk menambah kelenturan pada sifat mekanisnya sedangkan untuk bahan penguatnya (filler) menggunakan serat alami yaitu serat karbon Kevlar serat rami, dan serat agave, dari kombinasi tersebut diharapkan nantinya diperoleh data mengenai perbedaan daya tahan terhadap uji peluru [7].

Pada lapisan luar rompi anti peluru serat karbon digunakan karena serat karbon terkenal kuat dan keras, sesua dengan sifat yang diinginkan pada permukaan rompi yang dapat tahan terhadap gaya impak yang diberikan oleh peluru saat membentur permukaan rompi, dan pada lapisan kedua digunakan serat rami sebagai penguat (filler) ,dan pada lapisah terakhir penguat yang digunakan serat agave.

Dari latar belakang yang sudah dipaparkan, pada penelitian ini akan dilakukan penelitian mengenai daya tahan rompi dengan matrik epoxy yang dikombinasikan dengan karet dengan persentas jumlah karet 30\%, 40\% dan 50\% karet, Dalam penelitian ini spesimen material komposit yang dibuat akan dilakukan beberapa pengujian yaitu yang pertama uji kekuatan impak untuk mengetahui kekuatan persentase campuran karet yang terbaik pada material komposit, yang kedua uji tembak peluru untuk mengetahui ketahanan material komposit secara nyata dalam menahan laju peluru tembak standar NIJ 1010.04. level III. Setelah dilakukan pengujian tembak peluru pada produk panel rompi anti peluru maka dilakukan analisa kondisi material dengan foto makro dan foto SEM (Scaning Elektron Microscope) untuk mengetahui struktur kerusakan dari material yang telah diuji tembak.Dari hasil pengujian tersebut diharapkan nantinya terdapat perbedaan sifat mekanis dari material komposit dan semoga juga dapat di buat referensi untuk pembaca. 


\section{TINJAUAN PUSTAKA}

Rompi anti peluru merupakan baju pelindung yang digunakan di dalam dunia militer. Rompi tersebut dugunakan untuk melindungi badan bagian dada, perut, dan punggung. Organ-organ vital manusia terletetak diantara punggung dan dada seperti jantung, hati, paru-paru, organ-organ pencernaan dan ginjal dimana organ organ tersebut apabila terjadi kerusakan dapat berakibat dan vatal dan bahkan mengalami kehilangan nyawa seketika.

Komposit merupakan material multi fase yang didapatkan dari kombinasi material yang berbeda untuk mendapatkan material dengan sifat mekanik yang baru [3]. Komponen-komponen penyusun komposit tetap bisa dibedakan secara makro. Material komposit banyak diaplikasikan karena memiliki kombinasi sifat yang tidak bisa didapatkan apabila menggunakan materian konvensional seperti logam, polimer, maupun keramik. Sifat komposit bervariasi tergantung dari berbagai macam faktor di antaranya jenis komponen yang dipilih, distribusi komponen, dan morfologi komponen [2].

Epoxy memiliki kelebihan sifat Penyusutan material rendah, Sifat adhesif material baik. Ketahanan kimia material yang baik. Material memiliki sifta mekanik, seperti ketangguhan yang baik. Epoxy dapat diformulasikan dengan material lain maupun epoxy jenis lain untuk mendapatkan sifat sesuai keinginan.

Karet silikon ini di gunakan untuk campuran epoxy sebagai matriks pada komposit ini, silikon rubber mempunyai sifat yang tahan terhadap penuaan, tahan terhadap suhu tinggi, lentur yang di butuhkan untuk menahan tembakan putaran peluru karena kelenturannya.

Serat karbon adalah serat sintetis yang dibuat oleh manusia yang bukan dari alam. Jenis material yang satu ini punya arah dan bentuk serat penyusunnya sangat memengaruhi karakteristik material. Kevlar ini mempunyai berat jenis 1,44 gr/cc dan mempunyai kekuatan tarik kurang lebih $3620 \mathrm{MPa}$. Yang di harapkan bias menahan laju perluru.

Rami memiliki kompatibilitas yang baik dengan seluruh jenis serat baik serat alam maupun sintetis sehingga mudah untuk dicampur dengan jenis serat apapun selain itu rami juga ringan dan kuat terhadap impak. Dan mempunyai ketahanan tarik $95 \mathrm{~kg} / \mathrm{mm}^{2}$

Agave adalah tanaman monokotil asli dari kawasan Amerika Tengah dan Meksiko dan kini dibudidayakan di kawasan tropis lainnya seperti Malaysia, Kenya, Indonesia dan lain sebagainya. Tanaman ini tumbuh baik di daerah beriklim panas dan lembab, dengan suhu $15-30^{\circ} \mathrm{C}$. dan memiki kekuatan tarik $640 \mathrm{MPa}$.

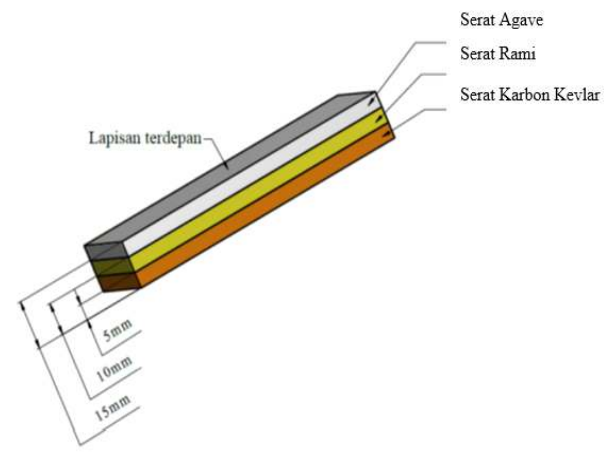

Fig. 1. Susunan pembentuk spesimen.

\section{METODOLGI PENELITIAN}

Peralatan yang dibutuhkan diantranya Mesin bor, Mesin gerinda, Gergaji kasar, Gergaji halus, Kunci kombinasi pas ring, Gunting, Kikir segi tiga, Alat pres cetakan, Cetakan, Rol cat, Kuas, Gelas takar, Amplas, Spet, Sarung tangan, Lap kain, Gelas tempat mencampur, Sendok, Timbangan gram digital, Jangka sorong, Mistar baja

Bahan yang digunakan diantaranya Wax, Cling wrap, Serat Penguat, Serat karbon kevlar, Serat rami, Serat kapas, Matriks, Polimer epoxy, karet silikon.

\section{ANALISIS DAN PEMBAHASAN}

Spesimen yang akan di uji impak dajn uji tembak dengan ukuran sesuai standart pengujian (Fig. 2 dan 3).

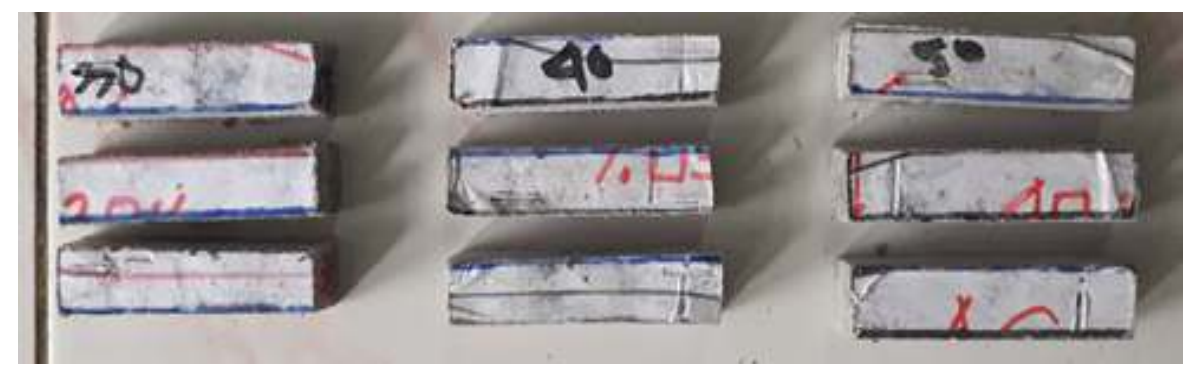

Fig. 2. Specimen uji impak. 


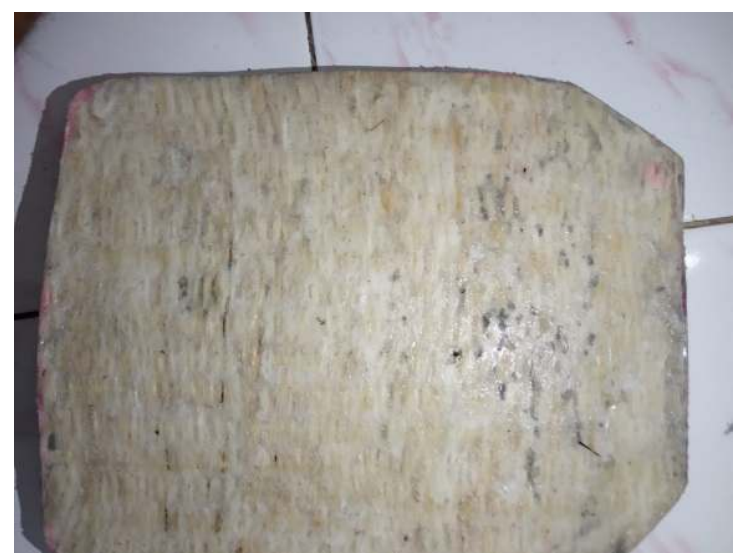

Fig. 3. Specimen uji balistik.

Dari hasil pengujian specimen didapatkan data seperti tabel 1 dan Fig 4.

TABLE I. DATA PENGUJIAN IMPAK

\begin{tabular}{|c|c|c|c|c|c|c|}
\hline $\begin{array}{c}\text { Variasi } \\
\text { persentase } \\
\text { karet }\end{array}$ & $\begin{array}{c}\text { Nomor } \\
\text { spesimen }\end{array}$ & $\begin{array}{c}\left(A^{\circ}\right) \\
\left(m^{2}\right)\end{array}$ & $\begin{array}{l}(\boldsymbol{\alpha}) \\
\left({ }^{\circ}\right)\end{array}$ & $\begin{array}{l}(\boldsymbol{\beta}) \\
\left.{ }^{\circ}\right)\end{array}$ & $\begin{array}{c}\text { Energi } \\
\text { (Joule) }\end{array}$ & $\begin{array}{c}\text { HI } \\
\left.\text { (Joule } / \mathrm{mm}^{2}\right)\end{array}$ \\
\hline \multirow{4}{*}{$30 \%$} & 1 & 80 & 45 & 37 & 1,548 & 0,0193 \\
\hline & 2 & 80 & 45 & 36 & 1,755 & 0,0219 \\
\hline & 3 & 80 & 45 & 37 & 1,548 & 0,0193 \\
\hline & \multicolumn{5}{|c|}{ Rata-rata } & 0,0202 \\
\hline \multirow{4}{*}{$40 \%$} & 1 & 80 & 45 & 37 & 1,548 & 0,0193 \\
\hline & 2 & 80 & 45 & 37 & 1,548 & 0,0193 \\
\hline & 3 & 80 & 45 & 37 & 1,548 & 0,0193 \\
\hline & \multicolumn{5}{|c|}{ Rata-rata } & 0.0193 \\
\hline \multirow{4}{*}{$50 \%$} & 1 & 80 & 45 & 38 & 1,429 & 0,0179 \\
\hline & 2 & 80 & 45 & 37 & 1,548 & 0,0193 \\
\hline & 3 & 80 & 45 & 38 & 1,429 & 0,0179 \\
\hline & \multicolumn{5}{|c|}{ Rata-rata } & 0,0183 \\
\hline
\end{tabular}

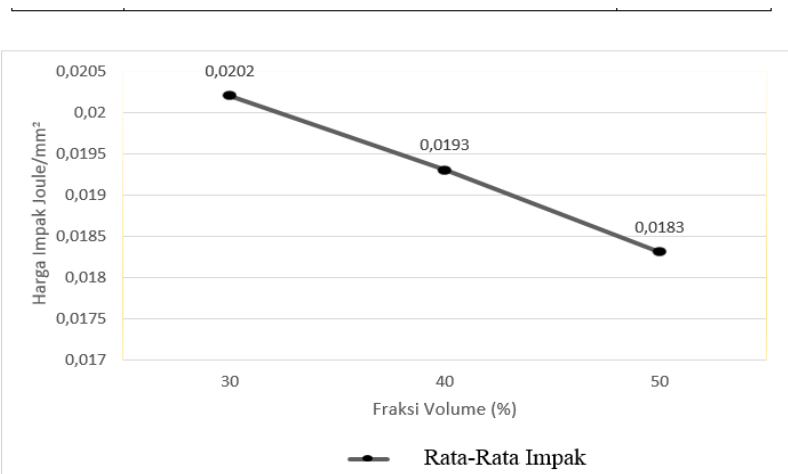

Fig. 4. Grafik hasil uji impak.

Dari hasil pengujian impak material komposit serat yang bermatriks epoxy dicampur dengan karet silikon sebanyak $30 \%, 40 \%$, dan 50\% memiliki rata-rata impak tertinggi pada $30 \%$ karet dan turun secara konstan pada campuran karet $40 \%$ dan 50\%, dan campuran karet 30\% memiliki kekeringan yang sangat maksimal dan mempunyai transfer tegangan yang baik, pada campuran $40 \%$ karet spesimen agak ulet dan transfer tegangan antar serat berkurang dan di campuran 50\% karet memiliki impak terendah dan juga spesimen sangat ulet dan transfer tegangan pada specimen tidak baik. Hal ini disebabkan karena semakin banyak campuran karet silikon pada material komposit menyebabkan material menjadi semakin ulet dan transfer tegangan oleh gaya impak tidak tersalurkan dengan baik dari matriks kesetiap serat penguat material komposit [6].

Dari hasil pengujian tembak produk panel rompi anti peluru dengan ketebalan $15 \mathrm{~mm}$ berbahan komposit serat karbon kevlar, serat rami, dan serat kapas dengan campuran 30\% karet silikon pada matriks epoxy yang dibuat oleh penulis dengan metode pembuatan hand lay-up ternyata tidak mampu menahan laju peluru tembakan pistol G2 elite pindad yang setara dengan standar NIJ 0101.04. Dilakukannya 1 tembakan dari arah depan produk dan 2 tembakan dari arah belakang produk yang ketiganya tembus. 
Dari perbedaan arah tembak tersebut menghasilkan besar kerusakan yang berbeda pula yaitu kerusakan bagian belakang tembakan. Tembakan dari arah depan produk memiliki kerusakan bagian belakang yang lebih kecil daripada kerusakan belakang yang ditembak dari arah belakang produk, hal ini disebabkan karena serat karbon yang memiliki kekuatan nilai tarik yang lebih besar daripada kekuatan tarik serat kapas sehingga pecahan akibat tembakan pada lapisan serat kapas lebih besar, luas, dan rapuh [5]. Sedangkan tembakan dari arah belakang produk memiliki timbulan kerusakan depan yang lebih tinggi karena serat karbon kevlar memiliki kekuatan yang tinggi untuk menahan laju peluru yang berputar daripada serat lainnya maka dari itu serat mengalami peregangan dan putusnya serat karbon kevlar juga tidak hancur rapuh seperti serat kapas akan tetapi hanya putus disatu sisi dan serat karbon kevlar menjadi tidak mampu masuk kembali keposisi awal serat (Fig 5,6,7).

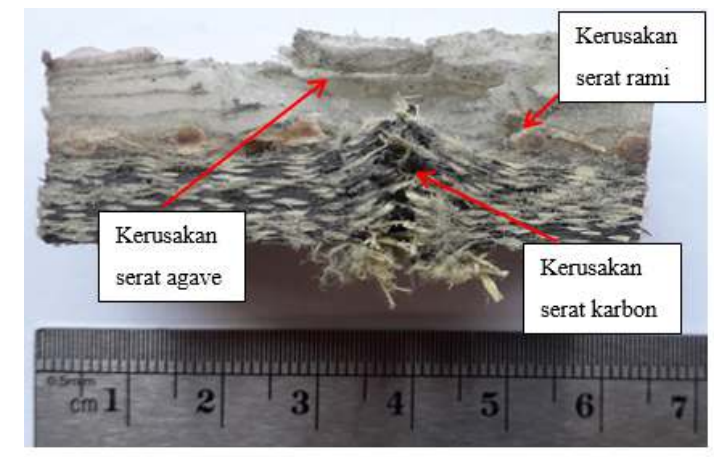

Fig. 5. Hasil foto arah serat.

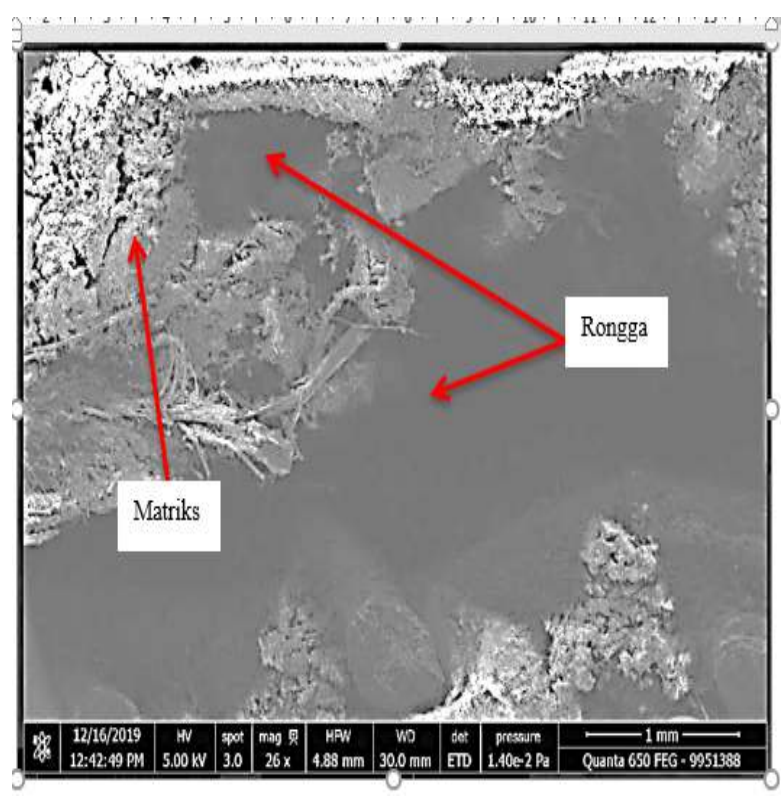

Fig. 6. Hasil foto SEM pembentukan cacat rongga.

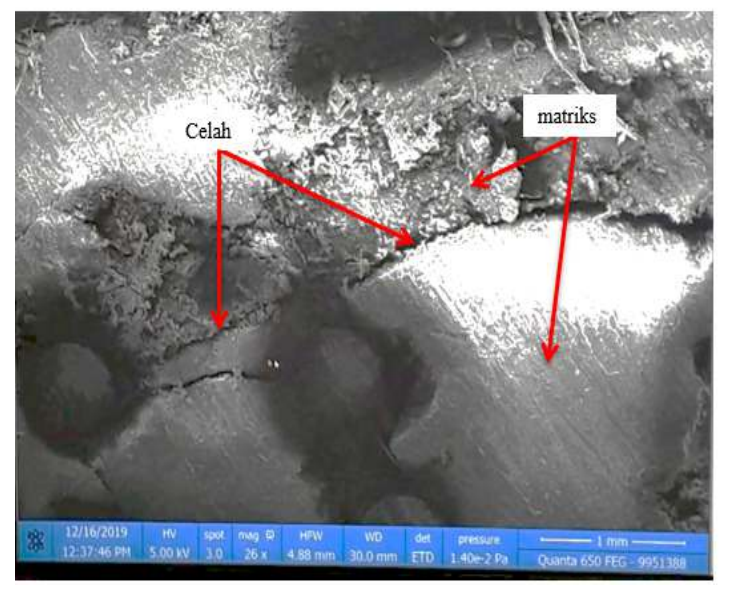

Fig. 7. Pengamatan SEM campuran matrik yang tidak merata. 


\section{KESIMPULAN}

Berdasarkan hasil penelitian yang penulis lakukan yaitu tentang analisa kemampuan komposit matriks epoxy-karet berpenguat serat karbon kevlar, rami, dan serat agave pada produk panel rompi anti peluru dapat disimpulkan hasilnya sebagai berikut:

- Produk panel rompi anti peluru dari material komposit laminasi matriks campuran karet silikon 30\% dan epoxy $70 \%$ berserat karbon kevlar 20 lapis, anyaman serat rami 1 lapis, dan anyaman serat agave 1 lapis dengan ketebalan total $15 \mathrm{~mm}$ belum mampu menahan laju peluru tembak Pistol G2 Elite Pindad yang setara dengan standar NIJ 0101.04 level III.

- Dari data foto makro dapat disimpulkan bahwa urutan lapisan serat yang baik berdasarkan perbedaan arah tembak pada produk saat pengujian tembak dari arah depan produk dan tembakan dari arah belakang produk adalah dari yang terlemah diletakan paling depan dan serat yang terkuat paling diletakan belakang.

- Dari foto SEM material komposit yang dibuat dapat dilihat bahwa masih banyak terjadi cacat pada material komposit seperti cacat rongga dan celah/retakan diantara matriks.

\section{SARAN}

Berdasarkan hasil penelitian yang penulis lakukan yaitu tentang analisa kemampuan komposit matriks epoxy-karet berpenguat serat karbon kevlar, rami, dan agave pada produk panel rompi anti peluru didapat saran sebagai berikut :

- Meminimalisirkan terbentuknya cacat rongga dengan lebih teliti saat menuangkan matrik keserat, sehingga produk kekuatannya meningkat untuk menahan laju peluru.

- Memperbanyak lapisan anyaman serat rami untuk meningkatkan kekuatan impak materiat komposit karena serat rami memiliki ikatan dengan matriks yang baik dan harganya relatif murah.

\section{DAFTAR PUSTAKA}

[1] Achmad Nurhidayat dan Wijoyo. 2014. Pengaruh Fraksi Volume Serat Cantula Terhadap Ketangguhan Impak Komposit Cantula-Hdpe Daur Ulang Sebagai Bahan Core Lantai Ramah Lingkungan. Jurnal energi dan manufaktur Pros iding SNATIF Ke -(1): 1-8.

[2] Aladin Eko Purkuncoro, Basuki Widodo, Anang Subardi, Penggunaan Fraksi Volume Komposit Serat Batang Pisang Kepok (Musa Paradisiaca) Orientasi Sudut Acak Dengan Matrik Polyester Terhadap Sifat Mekanik Jurnal Flywheel, Vol. 9 No. 1 (2018)

[3] Anang S., W. Sujana, Sibut, K.A. Widi, Peran Abu Sekam Padi Pada Komposit Polimer Jenis Pet, Jurnal Flywheel Vol. 8 No. 1 (2017)

[4] Hidayat Achmad. 2019. Analisa Kekuatan Tarik dan Kekuatan Impak Komposit Matrik Polyester Berpenguat Campuran Karbon dan Kapas. Skripsi. Fakultas Teknologi Industri Institut Teknologi Nasional, Malang.

[5] I Komang Astana Widi, Wayan Sujana, Gerald Adityo Pohan, Putu Suwendra Saskara, Analisa Uji Tarik Dan Impak Komposit Epoxy Rami Agave - Karbon dengan Campuran Epoxy-Karet Silikon (30\%, 40\%, 50\%), Jurnal Flywheel Vol. 11 No. 1 (2020)

[6] Komang Astana Widi, Wayan Sujana, Gerald Pohan, Luh Dina Ekasari, Analisa Orientasi Lapisan Serat Woven Memanfaatkan Teknologi Vacum Bag, Seminar Nasional Sains Dan Teknologi, Seminar Nasional Sains Dan Teknologi III, Universitas Brawijaya (2019)

[7] Sujana Wyn dan Astana Widi I Km. 2013. Pemanfaatan Silicon Rubber Untuk Meningkatkan Ketangguhan Produk Otomotif Buatan Lokal. Jurnal Energi dan Manufaktur Vol.6, No.(1): 1-94. 